\title{
Joseph Marx's New Songs
}

Author(s): Ernest Newman

Source: The Musical Times, Vol. 54, No. 839 (Jan. 1, 1913), pp. 10-12

Published by: Musical Times Publications Ltd.

Stable URL: http://www.jstor.org/stable/906100

Accessed: 06-05-2016 20:38 UTC

Your use of the JSTOR archive indicates your acceptance of the Terms \& Conditions of Use, available at

http://about.jstor.org/terms

JSTOR is a not-for-profit service that helps scholars, researchers, and students discover, use, and build upon a wide range of content in a trusted digital archive. We use information technology and tools to increase productivity and facilitate new forms of scholarship. For more information about JSTOR, please contact support@jstor.org.

Musical Times Publications Ltd. is collaborating with JSTOR to digitize, preserve and extend access to The Musical Times 
in place of another musician, ostensibly to / carving the Maoris achieve much beautiful work. found a college of music. He journeyed Mr. Balling thinks this aboriginal race is also really by way of Australia, and at Melbourne met musical, and capable of refined musical culture. the English musician, Mr. Marshall Hall, and Mr. Balling was brought back to England by heard under his conductorship the first Wagner Mr. Harold Large to conduct the music to concert ever given in Melbourne. He had 'A Midsummer Night's Dream' for Mr. Benson's booked his onward passage in the ill - fated company, on their tour through England, Ireland, Weirrarapa, but at the request of the Austrian and Scotland. In London he gave two recitals Consul he delayed his voyage two days. On on the Ritter viola, and a lecture before the arriving at Auckland, he found all the flags at Society of Musicians. For the play, he added to half-mast, and learned that the Weirrarapa Mendelssohn's music a chorus, 'On the ground, had gone down with all her 300 passengers. sleep sound,' which was much admired. The In the newspapers he read his own name tour began with a Festival at Stratford, and Miss among the list of the dead. He felt encouraged, Agnes Nicholls here appeared for the first time, and persevered to good purpose. Nelson, his destination, he found a most beautiful place, of I 5, 000 inhabitants. A Mr. Cock, of Devonshire, who was musical and spoke German, proved a great help. Balling soon discovered that he was expected to play pianoforte duets with the wife of Dr. Johannsen, a Dane, who, finding that he was not a pianist, shelved him entirely. He was stung by this incident into his first attempt to learn the pianoforte, and began his studies with the Prelude to 'Tristan'! After two months' stay he ventured, with little knowledge of English, on a public speech in behalf of his projected School of Music, and raised $£_{300}$ at his first meeting. The money was spent on instruments, which, some of them unknown in the land, aroused great curiosity when displayed in the shop windows. A NewZealander, Miss Dogtail, taught the pianoforte, and played well ; Mr. Balling taught all orchestral instruments and history. In his first harmony class there were twenty-three pupils, including a Colonel Branfield, who had been through the Indian Mutiny and was now over seventy years of age, and a little girl of nine years, daughter of Mrs. Houlker, the teacher of singing. Choral Societies were soon formed, and military brass-band players were quickly converted into wood-wind players for the orchestra. After two years' work the Music School had 200 pupils, and it still continues to be a prosperous institution. Before leaving he conducted Symphonies by Haydn, and the 'Walpurgis Nacht' of Mendelssohn. On visiting the King Country, Balling was much struck with the aboriginal music of the Maoris. In the forests bordering the Wanganui, the Rhine of New Zealand, the melancholy of their chants of mourning reminded him of some of the oldest Catholic hymns. With the corpse placed on a green-laurelled bier in their midst they chanted the story of the deceased, and over it all there was a solo contralto woman's voice, keening in quartertones in clear, six-eight time, a tune revolving about the central tone $\mathrm{D}$. Whenever a notable deed was recorded her voice was raised to a point of ecstasy, and always she ended with a falling sigh, like the groan of an animal. Their war-dance, with its strong, rhythmical shouts, ' $\mathrm{He}$, hu, hi, ha,' he found equally striking. At a Court Festival Mr. Balling played viola solos for the Maori King, and was presented with a stick deftly carved by means of fish-shells and stones. In this art of wood

A return, as assistant, to Bayreuth came in 1896 , when the first performance of the 'Ring' series was given since 1876 . Mr. Balling now became on friendly terms with the whole Wagner family. $\mathrm{He}$ was next appointed chorus-director of the Hamburg Stadt-theatre, and in eight months he prepared ninety different operas, and conducted all music behind the scenes, attending every rehearsal and every performance. This experience very much widened his knowledge. Here he wrote music also for the 'Christmas plays.' Called upon suddenly to conduct 'The Barber of Seville,' without preparation, he became obsessed with the idea that he might develop into a conductor. Soon afterwards he was appointed conductor at Lübeck, where he gave the first performance of the 'Ring' without cuts.

In this small town hegave thirty-four performances of 'The magic flute' to packed houses. He was next at Breslau, and then became successor to Mottl at Karlsruhe. Here he had his first experience of orchestral concerts, and gave all the Symphonies of Beethoven and Bruckner. At the Lyceum Theatre, Barcelona, he gave twelve performances of 'Die Meistersinger,' the first given there. He next conducted a Beethoven Festival in Rome. Then came an invitation to conduct 'Tristan' at Bayreuth, and his appointment as conductor of the 'Ring,' in succession to Richter. Afterwards illness compelled a year's rest, and he was next heard of as conductor of Mr. Denhof's operatic Festivals in Scotland and the North of England. His popularity on his appearance at Manchester in this connection virtually assured him succession to Richter, as conductor of the Halle Orchestra. How much Manchester expects of him may be guessed by the present support accorded him.

S. LANGFORD.

\section{JOSEPH MARX'S NEW SONGS.}

\section{By ERnest Newman.}

In the Musical Times for March, I9I2, I reviewed the songs of a remarkable new writer, Joseph Marx. These were published in two collections, the first containing twenty-eight songs, almost all of them of unusually distinguished quality, and a second set of nine, the general level of which was not so high, though one or two of the 
songs had the same fine flavour as those of the first set. The presumption was that the songs of the second set were compositions which the composer had at first withheld from publication, and had only issued after the success of the choicer things that comprised the first group. Some further collections of songs from his pen have now been issued. These consist of an amplified second set, containing the songs previously published, together with a number of new ones, a third set, and two small volumes of an 'Italienisches Liederbuch.' As Joseph Marx adopts the excellent practice of dating every song he writes, these four groups enable us to form a fairly clear idea of the course of his development.

In my previous article I pointed out that Marx's curious eloquence largely comes from the quality of his harmonic writing. His idiom is perhaps primarily Chopinesque, but in its onward course it seems to have assimilated almost everything that is good in the styles of Wagner, Wolf, and other moderns. It is impossible, of course, to trace an undeviating line of development through all the songs ; no man develops with such absolute consistency as that. Speaking broadly, the best of Marx does not emerge until about 1909. Yet so fine a song as the 'Wie einst' is dated I903,- - though it is not impossible that it has been touched up to some extent since that date. At first he seems to have written a good deal for the orchestra; one suspected even that certain songs of the first published set were originally planned for an orchestral accompaniment. In a footnote to one or two of the songs of the second set the composer admits that the accompaniments were originally orchestral; though the confession seems superfluous in view of the extraordinary difficultyindeed, impossibility - of the accompaniments on the pianoforte. This orchestral habit of thinking, though it has given range and richness to the composer's harmonic style, has not been without certain drawbacks. His harmonic speech was inclined from the first to a certain over-lusciousness; and the great range of colour and of line permitted by the orchestra did nothing to correct this tendency. $\mathrm{He}$ was tempted, indeed, both to over-design and over-paint his subject now and then. Writing more exclusively for the pianoforte has served to correct this bias towards excess of utterance. $\mathrm{He}$ has apparently now realised the force of Goethe's axiom that it is in his economy that the master reveals himself; it is really much more difficult to characterise a thing accurately with one adjective than with five or six. At the same time his orchestral way of thinking has endowed his pianoforte style with a fine polyphonic quality. With experience, too, his harmonic texture has become at once richer and simpler. A good many of the new songs in the second set are obviously the work of a young man who is only feeling his way. The 'Tuch der Tränen,' for example, is a perfectly horrible piece of harmonic experimentation; both in crudity and ineffectiveness it stands alone among Marx's work. In the best songs of the first set he is seen to have a very copious harmonic vocabulary, a very delicate poetic feeling, and a fully developed technique. His music resembles that of César Franck in the beautiful silkiness of its texture; even in its most poignant moments there is never an angular outline or a harsh note.

From his first set of songs one derived the idea that with all his art of poetic expression he had not the wide psychological range that makes Hugo Wolf's work so remarkable. This impression will probably have to be corrected in view of his later lyrics. It may still be true that there are certain poems with which he has some temperamental difficulty in dealing; though it is hard to say how far his failure in one or two cases may have been due to the lack of the right sort of imagination or to a certain immaturity of conception and technique at the time he wrote these songs. I have already pointed out that his imagination does not readily catch fire from a poem in which a certain sort of realism is almost inevitable. It is probably impossible, for example, to set Paul Verlaine's 'Il pleure dans mon cœur' adequately without some more or less veiled suggestion in the accompaniment of the falling of the rain. This semi-realistic sort of song, in which Schubert, Schumann, Wolf, Strauss and others have worked such wonders, is the kind in which Marx shines least. Other failures of his are no doubt to be attributed less to a fundamental lack of sympathy with the poem than to the fact of his having taken it up at a time when his technique was not sufficiently developed. Such a song, for instance, as 'Ein Fichtenbaum steht einsam' (I908) must be reckoned as one of Marx's comparative failures; yet it is practically certain that he could make a better setting of Heine's poem to-day. In his later songs he undeniably acquires new psychological territory. As I have said, we may take I909 as the great dividing line in his development. Previously to this there is a good deal that can be only put down as experimental ; during and after I 909 his mastery is assured. At the end of the expanded second set we have a remarkably fine song, 'Nachtgebet,' in which the fully developed Marx is quite evident. The harmonic writing here is as rich as, or richer than, that of the most complicated orchestral tissues of Marx's first youth, yet far more concise and consequently far more expressive. The problem before him in his latter years has plainly been the dual one of extending his poetic range while concentrating his musical style.

The third set of songs and the 'Italienisches Liederbuch' show how much he has accomplished in these two directions. From the first set one would have said that he was one of those musicians who, however intense their expression, remain visibly themselves in everything they write. To this order belonged men like Chopin, Grieg, and Schubert. In contrast with them are the musicians who seem instinctively to adopt a new style with each new subject they set to music. Wagner, Wolf, and Strauss are the three striking examples of this order of imagination. In the admirable 
third set we can see Marx's style beginning to take on a new form and colour in accordance with the atmosphere or the milieu of each song. It would probably have been impossible, for example, for him to have written three or four years ago such a song as the 'Piemontesische Volkslied.' Latterly he seems to have been studying Hugo Wolf. Not that there is any direct imitation of his predecessor ; but it is impossible to believe that a song like 'Sankta Maria' would have been written in precisely this form had Wolf not lived.

In the 'Italienisches Liederbuch' Marx's style undergoes a new extension; it takes in a wider mental range, and it achieves its result by simpler means. These poems of Paul Heyse seem, in fact, to have worked some such clarification in Marx's style as they did in that of Wolf. It would be a matter for surprise that these lyrics have been set with such comparative infrequency by previous song-writers, did we not recognise that until Wolf came the idiom of the modern song was hardly sufficiently developed to cope with them. They must be set to music as swift and concentrated as themselves, and with a like agility in change of expression. Not the least remarkable feature of the poems is their sudden modification of atmosphere at the finish; a lyric that apparently begins in a mood of passion will suddenly end upon an unexpected note of irony or menace; and it demands a good deal of concentration of musical style if these changes are to be expressed without an inartistic abruptness of transition. Wolf, with his fine faculty for unifying everything he did, solved these problems with consummate art. Marx's handling of them is hardly less successful. It may be true that without Wolf as a forerunner such a song as 'Die Begegnung' or 'Am Fenster' would never have been written at all, or would have been written in a very different manner; but all the same there is no direct imitation of Wolf, but only a dexterous utilisation of the new technique that he brought into the Lied. These songs are as thoroughly Marxian as any of those of his earlier days. For the rest, it is gratifying to note how aptly he now varies his musical idiom with the particular poem he is setting. This is perhaps the most interesting feature of the 'Italienisches Liederbuch,' though many of the songs themselves rank among the best work he has done. There is an unusual lightness of touch in such songs as 'Die Begegnung,' 'Wie reizend bist du,' ' Nimm dir ein schönes Weib,' 'Venetianisches Wiegenlied,' 'Ständchen' (a particularly charming song), 'Der Dichter,' 'Die Liebste spricht,' 'Abends,' and 'Wofür.' In 'Sendung' we have his quietly expressive style tuned down to a new and very effective simplicity; and in 'Die tote Braut' and 'Die Verlassene' he achieves a very poignant note of tragedy with a concision and directness that would have been impossible to him a few years ago. We shall now look forward with greater interest than ever to his next volume of songs.

\section{WHAT 'JOHN CHRISTOPHER' DID NOT SAY.}

By a PARISIAN.

M. Romain Rolland's book, 'John Christopher in Paris,' recently translated into English, has supplied the British public with a circumstantial -and rather pessimistic-description of musical life in the French capital; or, it would be more accurate to say, with a caustic censure of its shortcomings.

John Christopher's impressions, as set forth by M. Romain Rolland (who, it should be added, has given in his very commendable book, 'Musiciens d'aujourd'hui,' an optimistic counterpart to the passages under notice), cover the defects of the current répertoire of the Paris concerts, the critics' incapacity of dealing with music in a truly critical and at the same time artistic spirit, and the narrowness both of the modern French composers' ideals and of the musical coteries.

Under the first heading, for instance, come the lines: 'Music, German, Russian, Scandinavian, French-everything gulped down without winking. Practically nothing earlier than Beethoven, practically nothing later than Wagner. And what gaps between them! None of the old French masters, none of the great Italians. None of the German giants of the $I 7$ th and 18 th centuries. No contemporary German music, with the single exception of Richard Strauss, who was more acute than the rest, and came once a year to plant his new works on the Parisian public

We shall quote no more, as our present object is not to submit M. Romain Rolland's or John Christopher's views to discussion. And if we have quoted at all, it was with the intention of pointing to the fact that this description was written a number of years ago (our copy of the original French edition of 'La Foire sur la Place' bears no date, but we should say eight or ten years), and does not quite suit the present state of things. France, in musical matters, has progressed very rapidly and is still progressing. M. Romain Rolland's cry of warning, however, may have been quite to the point in its time.

But an additional chapter to John Christopher's experiences on the subject of musical life in Paris has remained unwritten. And our intention is to give a synopsis of what that chapter might have been-and, we are sorry to add, still might be. It should concern the attitude of the Paris Press towards musical matters, and would include topics not superfluous for the guidance of foreign artists in Paris.

For wealth of musical information and criticism, the French daily papers cannot compare with those of Great Britain and of other countries. The French public, in fact, does not seem to expect the dailies to keep it posted on forthcoming or on recent musical events; or if it does, the editors to a man disregard that very legitimate expectation. The duty is left entirely to the musical periodicals. And until the foundation, a couple of years ago, of a weekly Guide du Concert, 